\title{
Age, Feeling and Experience Framing a Modernist Vision in Panait Istrati's Stavro
}

\author{
Dana Radler \\ Bucharest University of Economic Studies \\ Faculty of International Business \& Economics \\ daniela.radler@rei.ase.ro, https://orcid.org/oooo-0003-0059-0832
}

\begin{abstract}
In Stavro, the first opening piece of Kyra Kyralina (published in 1923), the narrative focuses on the actions taken and the reactions shown or concealed by three male characters in alternation, with particular emphasis on gender, age, and experience. In between traditionally built sections and ample back-storytelling, the story addresses the key learning stances adopted by the three male characters at the end of a short trip that they complete together: reserve, reclusion and (self-)reflection. How does a modernist vision frame one's identity against age, common social norms and openly manifested repression in small urban neighbourhoods? Can one protagonist's understanding about his sexual orientation be genuinely shared with others? In what way does Stavro's personal experience alienate his prospects of family life in the port of Brăila? This paper aims to decode the narrative based on modern confession, continuity versus fragmentation, sexuality and modes of memory alter(n)ation.
\end{abstract}

Keywords: Panait Istrati, Stavro, modernism, confession, sexuality, memory.

\section{Introduction}

Panait Istrati was celebrated in France for his highly personal, deeply moving vision, exoticism and authenticity as soon as Romain Rolland prompted him to enter the international literary arena. He courted controversy in his home country, however, for writing the majority of his stories in French first and rather few in Romanian. His writing opens itself up to exploring a particular variety of modernism in Romanian inter-war fiction. Born in 1884 to Romanian Joița Istrati and Giorgios Valsamis, a Greek smuggler, both residents of the multi-cultural and heterogeneous area of Brăila (a growing Danube port), Istrati left home early, while still an adolescent, keen to learn about other cultures and experience life in a nonconformist way. He had to earn his living and underwent major hardships, but enjoyed finding those rejecting a bourgeois lifestyle. These encounters were for him the key to a durable and solid relationship with the other: he appreciated the companionship of ordinary individuals as much as that of prominent members of the European intelligentsia and engaged himself in friendship, affection or opposition with numerous individuals throughout his life. Various contributors have related Istrati's biography to his fiction when discussing an elusive figure such as Stavro, the main protagonist of the volume Kyra Kyralina (published in French in 1923). Ramona Dima (2018) suggests in her article about Adrien Zograffi, a character representing

(c) AesthetixMS 2021. This Open Access article is published under a Creative Commons Attribution Non-Commercial 4.0 International License (http://creativecommons.org/licenses/by-nc/4.o/), which permits non-commercial re-use, distribution, and reproduction in any medium, provided the original work is properly cited. For citation use the DOI. For commercial re-use, please contact editor@rupkatha.com. 
the writer's alter ego, that Istrati's stories belong to queer literature, yet her contribution screens a limited corpus presenting various expressions of sexuality: her paper focuses solely on Adrien Zograffi's Youth [Adolescența lui Adrian Zograffi] (p. 143-145), for reasons that remain rather unclear. Denise Roman (2007) briefly classifies the story Mikhaïl as a gay novel (p. 141), while for Alexandra Vranceanu Pagliardini (2019), the series of Greek characters populating Istrati's fiction, such as Stavro, Barba Yani and Captain Mavromati, feature both exotic, as well as symbolic elements. According to Livia Iacob (2014), Istrati's writing introduces specific bodily representations in Romanian modern fiction. Placing the characters in Kyra Kyralina and La Méditeranée - le lever du soleil along narratives of seduction and adventure, Angela Lăpădatu (2009) discusses the emergence of a feminine picaresque type (p. 138-142). Elena Dumitru (2012) refers to the journalistic and political background that prompted Pamfil S,eicaru, a well-known inter-war journalist, to accuse Istrati of homosexuality and servility to Christian Rakovski, the Soviet politician (p. 111). In his essay, Angelo Mitchievici (2019) discusses the Romanian novelist's vision of homosexuality as an expression of corruption of what he perceived to be natural in human behaviour. Turning his attention to the main hero, Călin Teutișan (2006) captures Stavro's appetite for journeys and his enticing personality (p. 145-150), while Paula Angelescu (2008) indicates how the central male and storyteller educates young Adrien to become an active listener, the result being a composite récit enchâssé (p. 71-78). These contributions examine elements related to the Romanian writer's main character or his biography (Mackiewicz 2018, p. 51), but have a less clear focus on such constituents as sexuality and time when inspected in relation to the narrative mode.

Following the development of literary genres in the eighteenth and nineteenth century, confession has largely moved towards autobiography. Thus, the confessional novel gradually abandons the scope of writing as religious revelation and its resulting detached tone, focusing on facts and actors and going into a fictionalized, occasionally less stable, highly fragile territory. The reason determining this change is threefold: firstly, the narrator switches from confession to autobiography because he does not necessarily tell all while engaged in a close relationship with the divine; casting a look upon the past, he practically assumes a similarly critical role to that of the celestial entity; secondly, being free from any repercussion or fear, the narrator gets the freedom to shape his voice and that of his protagonists; and thirdly, while confession implies restating all events in one's life journey (Foucault 1978, p. 61), the modern narrator decides how much to slice and how to wrap up his selection of events.

In order to explore Stavro, the present paper mainly employs the complex frame proposed by Susannah Radstone (2007). According to Radstone, three key modes shape the temporality of modernism: confession, nostalgia and memory. For her, the huge technological, economic and cultural changes of the nineteenth century impacted the way time was perceived and transposed into writing. As innovation and change became an increasingly powerful driving force in society, rising novelists recalibrated the focus of their writing, personalizing their stories more than ever before. Modern writers also became more concerned with topics such as sexuality, anxiety and trauma. After World War I, such subjects, sporadically present in earlier centuries, emerged as the focal point of the modern account, indicating a thematic shift, more distanced from the classical Balzacian construct and closer to the frequently fragmented, ego-centred narration. In her solidly grounded opinion, modernist writing should not be looked at as an unvarying production, since changes in both genres and personal writing style lead to clearly differentiated results. This paper relies on elements from Radstone's study, as well as other relevant sources addressing this particular story, opening its analysis to further debate. 


\section{Encounters or clashes: decoding modern confession}

Rather than accounts based on introspection, reflection and authenticity supported by a higher divine instance, typical of the Augustine confession, the modern writer deals with psychological transformations and discontinuities. The novelist usually undertakes this mission on his own, but may leave it to his readership in the form of open endings, multiple voices or other techniques. Events and characters mix with the imaginary and the result is a volatile mix: mainly first-personnarration, retrospection and anticipation. Given this frame, the narration opens up, the writer performing a double role: generating the outcome and having full control over it and, secondly, acting as the subject of a potential self-transformation, which hints at an intimate side, inaccessible to the reader except via secondary sources such as subsequent interviews or statements about his own writing. Debunking this transformation, Radstone observes that:

“the confession's construction of 'becomingness' [...] [lies] in the confession's concern with sexuality and suffering" (2007, p. 35).

Istrati places this story in his own hometown, the bustling cosmopolitan port of Brăila, renowned for its intense trade and multiculturality. Edmund Spencer highlights the local amalgam of ethnic groups in this Balkan growing metropolis:

"'in one place, under the verandah of a coffee-house, sat a crowd of Turks, languidly smoking the tchibouque: in another were to be seen, sauntering along the beach, a long range of most primitive-looking carriages, driven by Jews, Turks, Greeks or Moldavians, in their respective costumes, and attended by bare-legged footmen"' (Ardeleanu 2014, p. 57).

The story presents young Adrien, currently the apprentice of the local pastry and restaurant owner, Kir Nicholas, meeting Stavro, a controversial figure, who had returned to Romania after living in Turkey and Armenia for over one decade. They all head one late afternoon towards the fair in Slobozia, in the vast plain of Bărăgan, where Stavro needs Mikhail and Adrien's help to sell crêpes and lemonade, hoping to make a reasonable profit. Their trip is more melancholic than joyful to begin with: Adrien is feeling anxious and Stavro is voicing his own mournful state in Armenian through lamentation and singing. As they stop overnight, Stavro's sudden attempt to kiss Adrien stirs a heated discussion in which Mikhail blames the oldest protagonist of sexual abuse. The clash between all three indicates different levels of experience, expectation and inner struggle inflicted by this episode: Adrien swiftly goes through surprise and shock and hardly understands Stavro's erotic drive. The adolescent then listens to a dialogue in Turkish, which he cannot understand, while Mikhail attempts to restore order by making Stavro aware of his own actions. Upset by the incident and aware that he crossed a line regarding the intimacy of another human being, Stavro endures and fights his own torment, abandoning his earlier amusing role, in which he often played tricks upon passers-by. Once challenged by Mikhail, his own appearance undergoes a dramatic change:

"[h]e was ghostly pale, his mouth and his nose elongated, his moustache bristling. His eyes were sunken and he didn't look at them even when they themselves rolled their own cigarettes" (Istrati 2010, p. 20).

The old merchant's immediate physical transformation leaves a persistent mark on Adrien, who refers to the earlier and subsequent images of the lemonade seller in clearly contrasting tones. Stavro's alienating dissatisfaction with his own life determines him to return to Romania and rebalance his own self, comparing the expression of pity expressed by people in the case of a 
physically disabled individual with a deeper wound within one's soul for which there is no compassion. Mikhail, the Russian outcast rejected by society and Adrien's mother, intervenes from the position of a mature individual, verbally admonishing the lemonade seller. Stavro agrees to apologize in front of the two only after his peers accept to plunge with him into his own past. The confession he then delivers has a clear purpose: to extend his life experience over a learned Mikhaïl and temporarily immature Adrien. He had come back to Romania in 1867, as he confesses:

"crushed by the loss of my older sister and corrupted by the life of adventure I'd led for twelve years in search of her throughout Armenia and Turkey" (Istrati 2010, p. 21).

The author-protagonist relationship impacts the mode of confession, and so does the readerlistener acting as a sympathizer or critic of presented events and actors, shifting from an empathic and trusted pole of power to a challenging, unsettling one. In fact, subjectivity is the element eroding critical perspectives dealing with confession, autobiography, and memoir. As Radstone 2007) observes: “for some, the historical 'development' of autobiography reveals the genre's increasing incapacity to sustain the (always) illusory coherence of the autobiographical 'I'” (p. 31). In Stavro, the ambiguity between Istrati, the writer, and his fictionalized ego, the adolescent presenting the story, Adrien, lasts until the very end; typical for his accounts. Such vagueness enhances rather than obstructs the realism: facts and feelings conveyed to a modern readership. It also facilitates a permeable yet consistent relationship between the author and the reader. On the other hand, Adrien's surname is Zograffi, from the Romanian term "zugrav”, meaning 'house painter'. His surname connects him to the writer, who also worked in that trade; just as a house painter uses paint to change the feel of an interior, the writer combines reality with imagination. Adrien is therefore just like Istrati himself: an observer and a storyteller. The choice of "Zograffi",

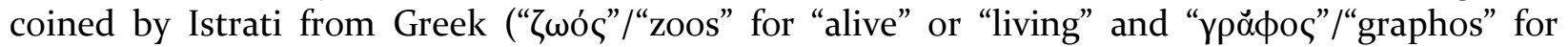
"painter" or "writer"), in which he was fluent due to his paternal lineage, connects the writer to the young protagonist and the writer thus affirms his artistic credo: portraying characters is associated, even if symbolically, with decorating one's house. Learning derived from experience is therefore as valuable as the artistic process of a genuine painter.

According to Teresa de Lauretis (1986), identity stands as the focal point of such a selfcentred memory quest: it "is not the goal but rather the point of departure of the process" (p. 9). From the tone of the narrative, rather than the facts presented as such, it appears that Stavro needs his testimony for both himself and the other two males. His decision to give it resides in the background elements: he feels that Mikhail and Adrien are different from the conservative voices of the mahala (Turkish: an urban deprived neighbourhood, a typical background to Romanian fiction). The community there had simply labelled him as a bizarre man whose failed marriage spiced up local gossip. Aware that the other two males possess two of the qualities the others lack, namely emotional and intellectual openness and the ability to learn from another's life journey, Stavro deserts his temporary attraction towards Adrien. By embarking on his confession, Stavro thus reaches an unforeseeable moral stand at the beginning of the story: the ageing man does not accept the judgement and forgiveness of humanity in its entirety because he has a low opinion of the average individual, who is unable to understand him. Yet he opens his heart in front of his companions and undergoes a painful yet necessary purification, thus becoming able to restore his dignity in front of a selected few.

\section{Locus, focus and tempora: continuity versus fragmentation}


In his essay dedicated to the works of Nikolai Leskov, Walter Benjamin (2006) considers that the presence of storytellers diminished gradually: once printing became largely available to the public, the novel was the new popular genre (p. 361-378). As he shows, both travellers and local tellers contributed to such accounts. Storytelling connects the raconteur with the other, as well as passing stories further on, from those like oneself. Istrati's story presents the young Adrien and the way that this character perceives the others, although his viewpoint follows a sinuous flow. Adrien starts his journey truly perplexed: "I'm no longer a child" (Istrati 2010, p. 7), he declares, as if to convince himself to act more independently further on. Secondly, as he voices it, social status and memory forge his identity:

"Who am I, myself? I am a housepainter, and before [that] I used to be the servant of the very same pastry cook. And if tomorrow I went to another country would folks there necessarily consider me worthless?" (Istrati 2010, p. 7).

His inner monologue certifies the hypothesis that the characters in this story need the other's confirmation, or at least understanding. Identity thus depends on social bonds and becomes inscribed in cultural memory as outlined by Maurice Hallbwachs in his pioneering study (1992). Set against a background marked by conventionalism and pettiness, in which his mother is a singular luminous presence, Adrien displays an early yet unstoppable drive for interaction with individuals like Mikhail, the mysterious intellectual concealed beneath the disguise of a rogue:

"As for pulling people's talk to make them talk, I'm not quite sure why I like to do it. Maybe it's because light shines out of the speech of strong people, as God proved when he spoke before there was light" (Istrati 2010, p. 8).

Referring to Biblical illumination ("The Light shines in the darkness, and the darkness has not overcome it" - John, 1: 5), Adrien thus assimilates close interaction to spiritual enlightenment. Stavro also alerts his interlocutors on the moralizing nature of his testimony, warning them that his confession serves as a lesson about life (Istrati 2010, p. 21).

Considering the perspectives of the main characters and the apparent continuities and discontinuities in their vision and discourse, Beata Piątek (2014) validates the vision of modern fiction as rejecting public history. For her, what modernism brings forward is the ability to focus "on an individual mind, [and on] experiments with chronology and explorations of memory" (p. 20). This takes place in Stavro along a natural shift to transpose shared memories into writing: Istrati recaptures, through the young narrator, Adrien Zograffi, the image that he could never escape:

"Stavro est la seule figure qui m'avait poursuivi et effrayé, pire que l'ombre de Banco pour lady Macbeth" [Stavro is the only one who pursued and scared me, worse than the shade of Banquo for Lady Macbeth] (Cahiers Panaït Istrati, p. 117).

In the same letter to Romain Rolland, his lifetime literary mentor, he confesses his blood connection with the individual he had never actually met:

"L’aïeule de Stavro, mère de sa mère, l'esclave roumaine du Turc, fut la tante de mon aïeule, la mère de ma mère" [Stavro's grandmother, his mother's mother, the Romanian slave of a Turk, was the aunt of my grandmother, my mother's mother] (Cahiers Panaït Istrati, p. 117). 
Three key aspects emerge from his letter: firstly, that Stavro, the real person, was deeply rooted in the past and Istrati only accessed his story by indirect accounts. This is unusual since his correspondence, complemented by literary sources to date, indicate that numerous real individuals inspired his stories, such as Mikhail, the Russian émigré, Nerrantsoula, the beautiful nameless adolescent, and Captain Mavromati, the destitute Greek commander etc. Secondly, Stavro's strong impact on the novelist's mind (over ten years) moved from communal memory into individual, literary modernist fiction. Thirdly, Istrati conveys his vision of the main character: he adopts a highly traditional, Christian-based frame, according to which Stavro's 'vice' can only be looked at from a subjective moral standpoint:

"J'ai horreur de son vice, qui m’avait malgré moi frôlé deux fois dans ma vie d'il y a vingt ans" [I hate his vice, which touched me twice twenty years ago despite myself] (Cahiers Panaït Istrati, p. 117).

In fact, Istrati's letter needs to be read in the context of the social and cultural background of the writer's upbringing. He shows that Stavro had been on his mind for ten years, and that he could not approach this figure until mentally confronting and clarifying his individuality. What surfaces from the letter to Rolland is the long gestation of the subject: ten years, and the way in which the writer embedded the core topic, a family saga, into his own aesthetic credo. The story becomes the outcome of a clearly-focused ten-day period in which he eventually managed to transfer it onto paper. Istrati openly expresses the concentration he needed to complete his deed and what Stavro ultimately represents for him:

"l'âme de Stavro est trouble et troublée, mais on a pu quand même voir jusqu'au fond ce qu'elle contenait. Cela n'arrive pas avec les eaux boueuses. J'en ai rencontré de celles-là, et peut-être leur ferai-je une petite place à contre-cœur" [Stavros's soul is anxious and confused, but we could nevertheless see what it contained. This is not the case with muddy waters. I have encountered the latter and might perhaps grudgingly accommodate them] (Cahiers Panaït Istrati, p. 120).

The first discontinuity in the narrative starts with an indirect, premonitory flashback. The narrator introduces the main protagonist based on Adrien's mother, who had shared with the teenager "the tale of an odious life" in line with the community's own perception: "[his] mother's house was closed to Stavro, as were all other houses" (Istrati 2010, p. 9). The lemonade seller's opinion about his own "dishonesty", together with the statement that he can no longer detect "honest rogues" (Istrati 2010, p. 13), leads Adrien in the direction that the lemonade seller wants: to join him in the short trip to Slobozia, together with Mikhaill. The peddler makes a voluntary choice when, at the debut of his life story, he declares that he will skip his childhood, or his sister's story, as he is going to concentrate on events elucidating his attraction towards Adrien. The narrative continues to follow a linear chronology except for two kinds of elements: those relating to Tincoutza and those relating to her family. Stavro has an initial attraction towards Tincoutza, but he quickly learns that her father, the owner of a prosperous business, needs a versatile man, a speaker of foreign languages and presumably a potential leader of his business, since his sons are unskilled merchants. Stavro is thus not an altruist, but combines his flair for a prosperous life with romance. Secondly, in order to solidify the relationship with Tincoutza, as well as with the other members of the family, Stavro, alias $\mathrm{Mr}$ Isvoranu, delivers sad or amusing stories that he extracts from his earlier experience. Such intermezzos create a necessary pause in the narrative, allowing the protagonist to further expose his past. Both these and the main narrative prove his storytelling talent: he describes characters, comments on their actions, criticizes their flaws and preserves a thoughtful tone regarding his own 
life journey. Stavro concludes his testimony by asking for Adrien's forgiveness, which emerges as a singular act compared to his past actions.

The story has a circular ending, presenting three negligible silhouettes set against the vast Romanian plain, with Stavro driving the peasant cart while singing to himself. The humans are hardly noticeable against the vast Bărăgan plain, their existence, even if modest, being assimilated to nourishment, without which life cannot continue. As Stavro sells lemonade and crêpes, and as he falls in love with Tincoutza, who is a good-looking "crâsmaritza" (Romanian: tavern owner), food equals a vital resource and hints at experience based on food of thought. Close to the end, the reference to "wheat" stands as a memento mori in the Christian tradition:

"If I were a lark

I'd glide in the blue sky

But I would never swoop down to earth

Where men reap wheat

Where men reap wheat

Where they sow and reap without ever knowing why..." (Istrati 2010, p. 38).

Istrati's story thus reveals continuity between the rural and the urban; time is a secondary factor, the storyteller being able to reconnect, via his narrative, with events and characters happening in in an earlier or later generation.

\section{Sexuality frames: desire, failure and death}

Physical attraction is a key ingredient, making the characters either pursue or restrain their actions and utterances. Yet social status surpasses physical appearance, which is the message emerging from the very beginning. Adrien's mother reproaches her son for being in Mikhail's company, since the latter is but an "outsider, a suspicious worthless servant of Kir Nicholas" (Istrati 2010, p. 7). Stavro definitely likes Adrien, and hides his intentions in front of Mikhaill. To secure their trip, he appeals to Mikhail to convince Adrien's mother to let her son join the trip, since Mikhail's presence was definitely an obstruction to his desire. In the episode of the attempted kiss, Adrien presents himself as a sexually inexperienced male, unable to correctly read a sexual intention. In contrast, Mikhail is more mature, immediately alerted by the contact and subsequent dialogue between the adolescent and the older male. He immediately seeks clarification by discussing directly with Stavro in Turkish.

As often the case in Istrati's stories, although certain gestures and actions appear as logically built, various details are left unclear. Why has Stavro taken both Mikhaill and Adrien with him on the trip to the fair, if Mikhail's presence was an impediment? If Stavro imagines that Adrien likes him, why does he proceed to direct physical contact instead of testing Adrien's interest towards himself? As he shows earlier in a brief encounter with Kir Margolis, when he asks the merchant to extend credit because business is low, Stavro possesses the instinct to get himself out of dangerous cases. When he gets closer to getting married to Tincoutza, he unexpectedly omits to sort out the dark side of his existence or to plan an escape sufficiently ahead of the ultimate confrontation and his wife's suicide.

Based on his testimony, Stavro mixes carnal impulses with a critical vision of other secondary personal benefits. In his short, often entertaining stories, the protagonists are ordinary peasants, the Roma, the Turks or representatives of the clergy. A short episode recounted by Stavro introduces two locals, a Romanian peasant and a Roma, thereby providing two distinctive economic visions: while the former thinks that he could escape poverty by selling the gold necklace owned by 
his wife, the latter, Trandafir, a passionate man, brutally teaches the peasant the following lesson: one can resort to horse stealing, if no other means works out to earn a living, but one can never sell the wife's jewellery: such ornaments are an intrinsic part of one's core assets, which cannot be given away. For the two, beauty works along alternative perspectives: while for Trandafir his wife's wealth adds to his own desire for her, the peasant has never admired his woman this much and expresses his weakness in front of life's adversities, for which he is severely admonished by the young Roma.

At the debut of his own story, Stavro refers to his promising prospects of a local crâshma (archaic for "tavern") on Ulitza calimereasca [Greek street]: his hope of finding a soulmate in Tincoutza, coupled with the naivety of the other members of the family, incapable of suspecting his real motive. According to the trader, it is the magnetism between himself and the young attractive woman sealing their fate: entering the place, he instantly observes her outstanding beauty, and turns into a "prey of the flashing black eyes of the one I idolized" (Istrati 2010, p. 22). Being later invited to a family meal, Tincoutza openly expresses her liking of him, indicating that Stavro is her choice as a husband. His courtship has predictable ups and downs: Tincoutza involuntarily pushes the seller into great turmoil when making the first close physical contact. Though she innocently asks if Stavro is able of a passion as intense as Trandafir's, her handshake makes the man aware of his current inability to deal with her bodily presence:

"my fear of finding myself alone with a woman manifested itself more than ever [...] I remained as I had been: a man with a contorted soul” (Istrati 2010, p. 28).

The family background is far from encouraging Stavro's repeated attempts to come closer to her, and train his mind and body towards a new experience. As he voices it, he feels deprived by the goodwill of the family members, as well as the wider social context: a second suitor's presence pushes him too swiftly into marriage. His apprehension is suggestive: "I felt my gut wrenching within me" (Istrati 2010, p. 29). Events take on a fast pace: the climax becomes predictable with Stavro's dread that the proof of the bride's virginity will be carried as a trophy flag on the street. This statement shows that Stavro's opinion upon this "hurtful and haunting practice" (Istrati 2010, p. 32) voices Istrati's own belief in educating the masses against such barbaric traditions. At the end of the nuptials, the family feels dishonoured by the peddler's alleged impotence and the family turns completely against him, except Tincoutza. Stavro's effort to overcome his addiction to homosexuality cannot be completed; psychologically, he does not find the means to express his sexual preferences. In a brief, visually-built representation, he muses on his sexual failure:

"I vaguely recall see my bride's lovely head on the pillow with her black hair spread out around her, but that's all. Right in the middle of the room I keeled over in a dead faint" (Istrati 2010, p. 33).

Tincoutza is his only support and light for the next ten months, believing in his honest affection and the works of black magic that could be ruled out by fervent praying. Virtually imprisoned on the family estate, the couple resists the persistent assault of all of the family members for ten months. Furious about their resistance, the family insistently demands that Stavro accept divorce.

The couple plans to escape this vicious environment, but the timing is against them: "The great wave of the men's hatred was about to inundate us” (Istrati 2010, p. 35). Tincoutza's anticipatory request for Stavro to stay at home does not help. Her two brothers finally bring in a Greek, a wanderer sharing Stavro's sexual orientation, who openly exposes the latter's alleged 
shameful vice. Tincoutza's vicious brothers brutally reprimand the guilty groom. Suffering from a severe fever, Stavro finds refuge in a kind Turk's house; four days later, his host discloses the news of Tincoutza's suicide in the Danube. The finale of his confession expresses missed opportunities and regret for the offence he had caused to the unique being who had loved him:

"Since then thirty-five years have gone by, and each year on that fatal date I go to the banks of the Danube with its floating ice sheets and beg forgiveness from Tincoutza for what I did to her" (Istrati 2010, p. 38).

His testimony and confession end with apologies to Adrien, a telling indication of Stavro's increasingly distanced moral profile from that of those inclined to judge: Adrien's mother, Tincoutza's family and Mikhaïl.

\section{Memory: alter(n)ation modes}

Istrati’s Brăila features the ambivalence of a developing urban setting typical of expanding Romanian settlements and ideal for the function of a modern storyteller. In her section dedicated to the interval spent by the novelist prior to World War I, Dumitru (2015) describes the young journalist's trips in connection with his militant activities, indicating his efforts to educate those whose ranks he joined in his youth: porters, apprentices, and painters etc. (p. 189-198). About nine years later, when asked by Rolland to write a preface to Kyra Kyralina, Panait Istrati expresses his surprise at such a task. The way he looks at his own production is far removed from a professional writer: "It was only by chance that I should have been plucked from the vast ocean of society [...]" (Istrati 2010, p. 3). He thought about his first story as an occasional piece, as he did not see himself turning writing into a long-term commitment. At the end, while addressing his readership, he offers advice towards the reception of his story: "you will first need to listen to the stories of others. "Please listen with him" (Istrati 2010, p. 3) he declares, referring to Adrien Zograffi, his fictional alter ego. For him, writing thus operates as a viable alternative to storytelling. It is the direct transmission to the recipient that counts and the format on paper only makes it available to a wider audience, supporting his vision of experience and learning affecting the minds of the masses. In doing this, Istrati endorses Benjamin's idea (2006) that storytellers transmit something practical and useful to their audience (p. 364). Although often critical to conformist views, whether at the level of a group or of an institution, the novelist has thus overcome the tension between the public and the private, dissolving paremiological components into the final literary product. Leaving the ending open, and wrapping up the finale in the verses of the anonymous poet, Istrati further connects with Benjamin (2006) when the German essayist states that outstanding stories do not force evidence on their readership, but preserve an "amplitude which information lacks" (p. 366).

Since the narrator, Adrien Zograffi, is both a witness and a storyteller, he accompanies the delivery of the testimony and appears in the posture of an active learner. At the same time, the confessional mode set by Stavro's story illuminates the whole reading in terms of the authority that the key protagonist instils in the intellectual and emotional space of his two interlocutors. From this perspective, Stavro's delivery validates Foucault's vision about the ritual of confession. The old seller's tragic account of his attempted reconciliation if not correction of the past implies a superior stance from the storyteller: by presenting his actions, as well as the actions and feelings of all protagonists involved, Stavro confirms that he holds what Foucault (1978) termed "pastoral" power (p.51-6o), a term understood to include both evaluation and repositioning of the self; this power also empowers the listener, who questions the story and gets meaning out of it. 
Looking at Stavro from the perspective of confession, the narrator builds a consistent temporal frame: firstly, the background and the onset of the journey completed by the three males, and secondly, the dramatic confession. While the testimony ends up openly, without revealing the effect on the listeners, it also supports an extremely painful self-discovery for the key protagonist. It therefore delivers a therapeutic function, necessary for the one telling it, and influencing the companions, instilling a mode of reflection and forgiveness. However, Stavro's open testimony speaks about an increasing need: to tell and to be remembered. Mark Freeman (Radstone \& Schwarz 2010) points out that what he calls "second-hand" material, namely "other others' memories", generate a first-hand production based on narrativization (p. 263).

The temporality of the whole narrative fluctuates: it is neither located in the past, nor related to the time of writing. This dimension can then follow several routes: a general line valid for all protagonists placed in the narrative, as well as individual facets mainly disclosed through their inner monologues. Moreover, the work of memory parallels the works of nature: Tincoutza's fate on the shore of the Danube, as well as Stavro's mention of the crushing ice sheets stand as symbolic elements of their destiny: the young woman has thus both cleansed herself and found refuge in the river, far from the reach of humans sealing off her marriage prospects. On the other hand, the widower contemplates the ice as a sealing layer of his failure, covering his only attempt at an ordinary life in the middle of a conventional community.

There is variation between the two narrative modes, but the story gently switches from Adrien, the young narrator, resident of the land according to Benjamin, to Stavro, the aged and disheartened adventurer. They both portray other characters in rather linear, straightforward tones: Adrien's mother is hardworking, modest yet unable to understand her son's interest in benign vagabonds such as Mikhaill, or individuals whom she avoids, such as the peddler. Even in Stavro's story of his failed marriage, the characters populating his youth share similar features: Tincoutza is sensual but naive, her father and his sons are labelled as narrow-minded and rigid, Adrien and Mikhail are 'honest rogues' and ordinary locals are but victims of his mockeries. The two raconteurs, Adrien and Stavro, gradually and deeply absorb the author himself and the narrative stands out as one coherent piece of the three-piece récit.

\section{Conclusion}

Stavro, the tragic protagonist of the eponymous story, left such a powerful grip on Romain Rolland when he first read Kyra Kyralina, that he immediately wrote back to Istrati, and declared that his series should be included in the line of great masterpieces, such as "[les] grands tigres du théâtre Elizabéthain" (Cahiers Panait Istrati 1987, p. 120). In addition, Stavro's act of remembrance suggests that although he cannot pardon the rigid psychology of the community in Brăila for causing Tincoutza's death, he is still willing to engage in a reparatory communal modus vivendi. Since he decided to continue staying there, instead of fleeing back to Turkey or Armenia, this position indicates that his recent social environment could be actually more welcoming than the places he had previously been in. A second interpretation might be that he is unable to leave the place until he finds emotional peace.

The narrative, supplemented by the correspondence between Istrati and Rolland, suggests a negotiation intrinsic to the artistic process: the writer reconfigures constitutive elements of his past, and gets additional advice on how to refine the material, highlighting certain elements (the interaction between the three males, or Stavro's intense affection towards Tincoutza), omitting or 
diluting others (the protagonist's life prior to meeting Tincoutza). According to the two correspondents, the ultimate aim is a product that cleanses the primary material and transmits as direct and condensed a message to the reader as possible. Thus, as Radstone (2007) indicates, memories blend together so that the resulting composites "are reducible to neither fantasy nor fact" (p. 197-8). Subjectivity, reconversion and confession develop as key features of this narrative, whose author convincingly builds highly temperamental personae engulfed in equally credible distinctive visions, except secondary characters, including Tincoutza, who are rather sketchy and therefore less plausible. Characters, time and place thus emerge as fluctuating variables of memory, sexuality and trauma.

The conversion of memories into the narrative practically articulates Istrati's ability as a particular modern writer of his time to:

"rewrite the world through the imagination, such that we, readers, can see or feel or learn something about it that might otherwise have gone unnoticed or undisclosed" (Freeman in Radstone \& Schwarz 2010, p. 275).

A confessional centripetal-centrifugal mode has thus become the driving force of this story, turning sexuality, suffering and the negotiation of authority into particular artistic ingredients. This particular narrative opens itself to additional debate about trauma or psychoanalytical criticism or a broader analysis of how cultural memory reconverts Istrati's stories extracted from his own past. Such efforts could also take the direction of looking at his fiction in connection with other modern novelists, either in Romanian or in European/American fiction.

\section{References}

Angelescu, P. (2008). Panaït Istrati et l'autre langue. La francophonie - les valeurs de la francophonie. Actes du Colloque International, Chișinău, ULIM, 21-22 mars 2008, coord. Elena Prus, Ana Guțu, 71-78.

Ardeleanu, C. (2014). International Trade and Diplomacy at the Lower Danube: The Sulina Question and the Economic Premises of the Crimean War (1828-1853). Editura Istros a Muzeului Brăilei [Istros Publishing House of Brăila Museum].

Benjamin, W. (2006). The Storyteller: Reflections on the Works of Nikolai Leskov. In D. J. Hale (ed.), The Novel: An Anthology of Criticism and Theory, 1900-200o (pp.361-378). Blackwell Publishing.

Cahiers Panaït Istrati. (1987) Christian Golfetto (coord.), Numéro special 2 - 3-4, Fondation Panaït Istrati.

Lauretis, T. D. (ed.) (1986). Feminist/Critical Studies. Macmillan.

Dima, R. (2018). Queer Romanian Literature: A Selection of Gay and Lesbian Characters from the 2oth Century to the Present. Lambda Nordica 1-2/2018, 143-145.

Dumitru, E. (2015). Pacifist Writers and Soldiers Writers in Romania of the Great War. In A. Biagini, G. Motta (eds.), The First World War: Analysis and Interpretation (pp.189-198), Vol. 2. Cambridge Scholars Publishing.

Dumitru, E. (2012). L'emigrazione intelletualle dall' Europa centro-orientale. Il caso din Panait Istrati. Edizioni Nova Cultura.

Foucault, M. (1978). The History of Sexuality, Vol. 1: An Introduction. Pantheon Books. 
Hallbwachs, M. (1992). On Collective Memory. L. C. Coser (Ed., Transl. and Intro). The University of Chicago Press. (Original work published in 1952, 1941).

Iacob, L. (2014). Ménage à trois în infernul interetnic: trupul feminin şi privirea celuilalt în romanul balcanic recent [Ménage à trois in an interethnic inferno: the feminine body and the other's sight in the recent Balkan novel]. Philologica Jassyensia, X (1 suppl.), 337-347.

Istrati, P. (2010). Kyra Kyralina (transl. by Christopher Sawyer-Laucanno). Talisman House.

Lăpădatu, A. (2009). Le Picaro féminin de Panait Istrati. Language and Literature - European Landmarks of Identity, 5 (1), 2009, 138-142.

Mackiewicz, S. (2018 [1932]). Russian Minds in Feathers, George Allen \& Unwin.

Mitchievici, A. (2019). Sexualitatea damnată și literatura gay românească [Damned sexuality and Romanian gay literature]. Dilema Veche, 24 septembrie 2018, https://dilemaveche.ro/sectiune/dileme-online/articol/sexualitatea-damnata-si-literatura-gay-romaneasca, accessed 20 February 2019.

Piątek, B. (2014). History, Memory, Trauma in Contemporary British and Irish Fiction. Jagellonian University Press.

Radstone, S. (2007). The Sexual Politics of Time: Confession, Nostalgia and Memory. Routledge.

Radstone, S., Schwarz, B. (eds.). (2010). Memory: Histories, Theories, Debates. Fordham University Press.

Roman, D. (2007). Fragmented Identities: Popular Culture, Sex, and Everyday Life in Postcommunist Romania. Lexington Books.

Teutișan, C. (2006). Panait Istrati, « L'espace littéraire levantin ». Synergies Roumanie, 1.

Vranceanu Pagliardini, A. (2019). L’image du Grec dans l'œuvre de Panaït Istrati et Mateiu Ion Caragiale. Cahiers balkaniques [Online], 44 | 2016, Online since 28 November 2017, connection o9 February 2019. URL : http://journals.openedition.org/ceb/9719; DOI : 10.400o/ceb.9719.

A graduate of the Faculty of Foreign Languages, Dana Radler completed her PhD with a thesis on "Memory and Fiction in John McGahern's Works" (a contemporary Irish writer). Her current research topics combine memory, gender and culture in fiction as articulated components of modern societies, and occasionally aspects related to ESP practice. She has published articles in academic journals in Sweden (Swedish Journal of Romanian Studies, 2018), Turkey (Folklor/edebiyat, 2018) and Romania (Philologica Jassyensia, 2019; British and American Studies, 2018; Synergy, 2016, 2017, 2018; American, British and Canadian Studies, 2016) and various book chapters in collective volumes published in Italy (2020), Poland (2019) and Romania (2020, 2019 and others) on modern or contemporary authors. In 2018, she was co-editor of a thematic issue of journal Synergy (Romania), including ten contributions focusing on "East and West within Interdisciplinary Frames". At present, she is Assistant Professor in the Department of Modern Languages and Business Communication at the Faculty of International Business \& Economics, Bucharest University of Economic Studies. 